\title{
Political Realism and International Relations
}

\author{
Duncan Bell
}

\section{Introduction}

Writing a survey of realist political theory and international relations might strike some as a quixotic enterprise, even a waste of time. After all, many political theorists seem to believe that realists view the world solely through the prism of power politics, denying any significant role for normative judgement. According to Allen Buchanan, realists think that the "nature of international relations rules out morality in that sphere" (2003: 29), while Charles Beitz asserts that for realists, "moral judgments have no place in discussions of international affairs or foreign policy" (1999: 15). Jürgen Habermas, too, joins the chorus: realism, he claims, constitutes the "quasi-ontological primacy of brute power over law" (2006: 161). What, we might ask, can realists possibly have to say about such fundamental topics as the ethics of war and peace, global inequality, the legitimacy of international institutions, or climate change? In this brief article, I show that the picture of amoral realism is a caricature, discuss assorted realist arguments about international relations, and identify a number of issues that realists need to address. In particular, I argue for greater engagement between political theorists and International Relations (IR) scholars.

\section{Ships Passing? Political Theory and IR}

Assessing the state of contemporary realism can induce vertigo or prompt flights of fancy. "Recently," William Scheuerman writes, "I have experienced the odd, science fiction-like experience of residing in two parallel universes, each employing similar conceptual parlance and preoccupied with related concerns, but whose respective residents remain unaware of their doubles elsewhere" (2013: 798). The parallel universes are the scholarly subfields of political theory and IR. Given the lack of conversation across subfield boundaries, Scheuerman's disorientation is understandable.

Realism of one kind or another has long been a central theme in IR, especially in the United States. "It is only a slight exaggeration," William Wohlforth once observed, "to say that the academic study of international relations is a debate about realism" (2008: 131). Though less prominent than it once was, it remains a substantial research program and a staple of pedagogy in the field. Its proponents tend to focus on geopolitical relations between states, arguing that the lack of an overarching political authority in the international system - the condition of "anarchy" - means that the potential for reform is very limited. States remain the key agents in international politics, and they almost invariably act in self-interested ways. The result is a "tragic" world in which war is an ever-present possibility, national security stands at the centre of government decision-making, and international co-operation is fragile. Yet realists do not speak with one voice. Indeed IR realism can be divided into two distinct (and internally diverse) strands: neo-positivist and non-positivist. ${ }^{1}$ Non-positivists are sceptical of claims to objectivity in

I would like to thank the following for offering helpful comments on this essay: Matthew Sleat, Alison McQueen, and Philippe Bourbeau. All the usual disclaimers apply. 
social science and as a result they tend to engage seriously with history, sociology, philosophy and law. Standing outside the mainstream of contemporary social science (at least in the United States), they see realism as an explicit contribution to political theory as well as the empirical analysis of international politics. I will discuss some examples later in the essay. Neo-positivist realism, on the other hand, encompasses most of the work in IR that has been classified as realist in the last four decades. Scholars of this stripe claim they are engaged in an explanatory or descriptive form of inquiry, not a normative or evaluative one - they aim to tell us how the world is, not how it should be (for an overview, see Wohlforth (2008)). To do so they utilise realist theoretical frameworks to generate hypotheses about state behaviour, which are then "tested" using various forms of empirical evidence. They are adamant that this brand of realism is different in kind from the work of political theorists - it is an alternative mode of intellectual activity. Prominent advocates of this approach include Kenneth Waltz (1979), John Mearsheimer (2001), and Randall Schweller (2006). The lack of serious dialogue between such realists and international political theorists is unsurprising.

Neo-positivist realism might nevertheless be relevant for political theory in (at least) two senses. First, it can inform debates about the feasibility of normative proposals - a central issue in contemporary methodological debates over both realism (e.g. Bell 2017) and the status of "ideal" theorising (e.g. Valentini 2012; Lawford-Smith 2013). ${ }^{2}$ If one (a) accepts the plausibly of realist empirical accounts of international politics, and (b) thinks that it is important to develop "nonideal" political theories, then realism challenges the viability of much current work on global justice. However, many would agree with Jack Donnelly's contention that realists "regularly, sometimes spectacularly, overstate the nature and significance of the 'facts' that constrain the pursuit of moral objectives in (international) politics" (2008: 153). Indeed it is notable that most global justice scholars reject realist empirical accounts, relying instead on liberal IR theories which fit better with their reformist agenda (though see Nili 2016). Second, despite protestations to the contrary, neo-positivist IR realism can be seen as a form of political theorising, albeit of a rather etiolated kind. It encodes all kinds of normative assumptions, about human nature, social organisation, and political institutions, and it has substantial consequences for thinking about how best to act in the world. It takes a stand, in other words, on a wide range of evaluative questions (for a critique, see Donnelly 2000). Indeed even if we accept their claims about social scientific neutrality, realist IR scholars usually draw normative implications from their analyses. Thus Mearsheimer argues that "states should behave according to the dictates of offensive realism, because it outlines the best way to survive in a dangerous world" (2001: 11). Normative prescription is yoked to - and constrained by - the conclusions of the empirical analysis. Yet the picture presented in the neo-positivist literature is usually both normatively underdeveloped and conservative. This is what led Stanley Hoffmann to complain that IR needed to move away from its relentless focus on "a superpower perspective (and a highly conservative one)" (1977: 59). More recently, Scheuerman has charged that contemporary realism is often a "stodgy and rather self-satisfied defence of the international status quo" (2011: vii). This doesn't mean that realists are uncritical supporters of the foreign policy advocated by the United States or its allies - after all, most were vocal critics of the 2003 war in Iraq (Jackson and Kaufman 2007; Van Rythoven 2015), as their predecessors had been of Vietnam (Zimmer 2011). Rather, they rarely challenge

${ }^{1}$ I am aware of the difficulties of using the term "neopositivism" to encompass this body of work, but in the absence of a better alternative, I follow Jackson (2010) in employing it as a place-holder.

${ }^{2}$ It is important to note that while most contemporary political theory realists take questions of feasibility very seriously, they do not reduce realism to such concerns (Sleat 2017b; Sleat and Rossi 2014). 
the underlying structures and norms of the international system. Theirs is a policy science designed for a world of great power politics, tailored to guide the decision-making of the dominant states.

Realism has played a far less pivotal role in political theory. It is only in the last decade or so that a self-conscious realist position has begun to emerge in the field, though it draws on various long-standing lines of thought (for surveys, see Bell 2008a; Galston 2010; Sleat \& Rossi 2014; Sleat 2017a). The recent burst of writing has been inspired above all by the work of Bernard Williams (2005) and Raymond Geuss (2001; 2008), although numerous other thinkers have also been recruited to the cause, sometimes retrospectively. Chantal Mouffe, James Tully, John Dunn, Stuart Hampshire, John Gray, David Runciman, William Galston, Jeremy Waldron, Judith Shklar, Marc Stears, Mark Philp, Bonnie Honig, Noam Chomsky, Michael Freeden, even Gandhi: all have recently been characterised as realists. Their political and theoretical diversity highlights the difficulty of identifying the core features of realism. There is a lot to be said for Mark Philp's claim that realism is less a unified body of thought than an "intellectual moment of resistance" (2012: 361) against trends that have dominated Anglo-American political theorising since the 1970s. Elsewhere, I have suggested that realism is perhaps best defined negatively - by what realists reject, rather than what they positively endorse (Bell 2017; 2008). They reject what Geuss refers to as the "ethics-first" approach (2008) and Williams terms "political moralism" "the priority of the moral over the political" (2005: 2). "To engage in moralizing," Geuss writes, "is to make a moral judgment in an inappropriate context, that is, to propound it in a context or in a way which seems to ascribe to it too much of the wrong kind of weight or effectiveness" (2016: 96; see also Coady 2008). Moralism, realists charge, has rendered mainstream political theory incapable of grasping the nature of politics.

Moralism is not only a pathology afflicting academic debate; it affects the wider political world in profoundly damaging ways. The international realm is particularly susceptible. Where institutional ties are thin, David Runciman argues, it is much easier for moralists to "mould contingency and the claims of legitimacy to their own purpose." Moralism thus follows the "path of least resistance" (2016: 8). The most glaring recent instance of this phenomenon is the evangelical "conviction" politics that drove the Bush and Blair administrations into war in Iraq (see also Runciman 2006). More an ideological product of think tanks than philosophy seminars, neo-conservatism exemplifies a dangerous moralizing stance in foreign policy.

In contrast, realists insist on the importance of contingency, historical context, prudence, and the limits of moral argumentation. They demand that politics be assessed on its own terms. "Realism seeks," that is, "a way of thinking normatively about politics that is suitably sensitive to the conditions and features of the political sphere, with the hope that doing so will provide us with theories befitting the actual practices of politics" (Sleat 2017b). Consequently, realism is a "distinctive family" of approaches that

(a) affirm the "autonomy" (or, more minimally, the "distinctiveness") of politics; (b) hold an agonistic account of politics; (c) reject as "utopian" or "moralist" those approaches, practices, and evaluations which seem to deny these facts; and (d) prioritize the requirements of political order and stability over the demands of justice (or, more minimally, reject any kind of absolute priority of justice over other political values) (McQueen 2017a).

Beyond these general similarities, realists diverge on numerous issues. While both Geuss and Williams reject moralism, they do so with very different political ends in mind. Williams was keen to save liberalism - understood as the best ideological response to the politics of modernity 
- from misguided liberal political philosophers. Geuss, on the other hand, comes to bury liberalism - understood as the justificatory ideology of a malevolent capitalist order - not reanimate it. We see, then, a notable split between liberal realists and those with more radical political commitments. However, both groups are united by a failure to pay much attention to international politics (Bell 2008; Scheurman 2013; Rossi \& Sleat 2014: 696-7). Given the deep impact of international and/or global processes - including violence, capitalism, poverty, and climate change - on nearly all aspects of politics, this challenges the credibility of their claims to be offering a properly realist account.

We are left, then, with a striking gap. Realists in political theory have had little to say about international politics. IR realists, meanwhile, have tended to disavow normative reflection, focusing instead on pursuing empirical social science. In the remainder of this essay I survey some of the most notable exceptions.

\section{Reclaiming History}

While realists insist on the importance of history, they utilise it in different ways. In this section I discuss those who develop their realist accounts through engaging the (shifting) canon of realist political thought. ${ }^{3}$ In the following section, I turn to those who try and build an appreciation of the centrality of history into their theories, but do not engage in the sustained historical interpretation of past thinkers.

In recent years non-positivist variants of realism have become increasingly popular in IR. They have made a significant contribution to the cross-disciplinary field of "international political theory." Among the most prominent examples of this genre are Richard Ned Lebow's The Tragic Vision of Politics (2003) and Michael Williams's The Realist Tradition and the Limits of International Relations (2005). Despite their differences, they share much in common. Both deny the neopositivist distinction between explanatory and normative theorising, acknowledging the impossibility of developing neutral "scientific" theories. Both deny a strict separation between "domestic" and "international" politics, one of the pivotal assumptions of much (though not all) recent "structural" neopositivist realism (e.g. Waltz 1979). Both critique the "rationalism" of mainstream IR, and in particular its reliance of utility-maximizing models of action imported from economics. Moreover, they reject any institutional or intellectual divide between political theory and political science. Lebow and Williams are also clear that their political positions are not antithetical to liberalism, but are rather instantiations of it.

Michael Williams (2005), for example, builds a creative argument inspired by Richard Flathman's "wilful" liberalism. He argues that we can identify a "wilful realist" position in the writings of Hobbes, Rousseau, and Morgenthau. Seeking to map the "politics of modernity," these writers, he suggests, are united by three key theoretical commitments: Scepticism - the rational questioning of the limits of human reason; Relationality - an acknowledgment that identities, whether individual or collective, are dynamic and mutually constituted; Power politics - a focus on the pervasiveness of power, encompassing both its constructive and destructive dimensions. "Wilful realism," Williams argues, "is deeply concerned that a recognition of the centrality of power in politics does not result in the reduction of politics to pure power, and particularly to the capacity to wield violence." Instead, it seeks "a politics of limits that recognizes the destructive and productive dimensions of politics, and that maximizes its positive possibilities while minimizing its destructive potential" (2005: 7). More recently, he has drawn on Judith Shklar's (1989)

\footnotetext{
${ }^{3}$ For methodological reflections on canon formation, see Bell (2008b; 2014a); McQueen (2017d).
} 
"liberalism of fear" to critique the culture of insecurity in contemporary democratic societies (Williams 2011).

In a series of provocative articles and books, Scheuerman has retold the story of twentieth century realist international thought and made a powerful case for its contemporary significance (2010; 2011; 2013; 2014). He argues that political theory realists, including Williams and Geuss, often unwittingly repeat the arguments of mid-twentieth century realist scholars - and that they lack the persuasiveness, subtlety, and empirical richness of the earlier writers. Contemporary realist political theory, he concludes, represents an "anti-Kantian gesture" but not a proper alternative. In The Realist Case for Global Reform (2013) he sets out his most detailed argument for the continuing salience of the earlier generation. First, he challenges the conventional narrative that realism is a conservative position that rejects the role of morality and valorizes state power. He demonstrates the complexity (as well as the limitations) of their political analysis, and identifies a "progressive" realist position defended by a group of sophisticated liberal or leftwing thinkers, including Hans Morgenthau, John Herz, Reinhold Niebuhr, Frederick Schuman, and Georg Schwarzenberger. In particular, he emphasizes how they argued that the development of nuclear weapons called into question the viability of a system based on territorial states - some of them even demanded the creation of a world state (see also Craig 2003). ${ }^{4}$ The threat of nuclear war, Morgenthau once proclaimed, "suggests the abolition of international relations itself through the merger of all national sovereignties into one world state which would have a monopoly of the most destructive instruments of violence" (1962: 174). As such, Scheuerman argues, the "progressive" realists can be seen as forerunners of contemporary advocates of cosmopolitan political order. He also argues, though in less detail, that they have lessons to teach contemporary international political theorists. For example, he contends that cosmopolitans need to acknowledge both that states are the key agents for realizing justice - "[o]nly a system of binding law, backed up by the not inconsiderable power of the state, can properly ensure a modicum of political and legal reciprocity and equality" (2011: 151) - and the necessity of creating firm social foundations for sustainable global political institutions (see also Scheuerman 2014).

Alison McQueen has argued convincingly for the "kinship" between classical IR realism and recent political theory realism (2017b), suggesting that they share a basic set of normative and conceptual commitments. Like Scheuerman she contends that the latter group have much to learn from the former. She develops this argument, with striking originality, in Political Realism in Apocalyptic Times (2017b). Drawing on three seminal figures in the realist canon - Machiavelli, Hobbes, and Morgenthau - she proposes that realism (or at least an important strand of it) is best grasped as a tradition of thought characterised by the attempt to neutralise expectations of apocalypse - a mode of utopianism based on a belief in the imminent end of the world, and its replacement by a new order of things - and the dangerous forms of politics that such expectations engender. In particular, she identifies two main strategies to respond to apocalyptic thinking: rejection and redirection. The former seeks an alternative understanding of politics, the latter fights apocalyptic politics by (re)deploying aspects of apocalyptic thinking. She utilises this illuminating distinction to make sense of the political thought of the three thinkers. Thus she argues that in his early work Morgenthau adopted the rejectionist line, castigating the Manichean views of many of his contemporaries. In the 1950s, however, he turned to the strategy of redirection to confront pervasive fears about nuclear war. He did so by invoking the spectre of

${ }^{4}$ Rens van Munster and Casper Sylvest $(2014,2016,2017)$ argue that the period saw the development of a form of "nuclear realism." They explore how a disparate group of midcentury theorists - chiefly Günther Anders, Bertrand Russell, John Herz, and Lewis Mumford attempted to grapple with nuclear weapons. 
atomic apocalypse and species-extinction to justify the creation of a world-state. While this type of argument is only relevant in certain political contexts it nevertheless remains pertinent, and McQueen employs it to shed light on contemporary discourse about global climate change.

Scholarship of this kind illustrates another key feature of much realist international political theory: an emphasis on intellectual history. Indeed the main way in which realism has been discussed as an ethico-political theory is through the historical exegesis of past thinkers, perhaps above all Morgenthau. ${ }^{5}$ Detailed historical interpretations are utilised to develop theoretical propositions suitable for the present world. This approach can generate innovative theoretical arguments. Moreover, the work of historical recovery is very welcome - it provides a rich account of the development of international theory, dispelling many of the long-standing myths about the topic that have structured the historical memory and pedagogy of IR. Once we take this history seriously, we see that the idea of a discipline structured by "great debates" and a titanic clash between realism and "idealism" is largely illusory. ${ }^{6}$ Moreover, it adds a longneglected dimension to the study of twentieth century Euro-American political thought and the history of the human sciences. Finally, it can help political theorists avoid reinventing the wheel. But the emphasis on history arguably comes at a price. While it is now widely recognised in IR that realism is a far more subtle position than many of its critics once assumed, there has so far been little methodical realist normative theorising about contemporary global issues. The work we have, insightful and challenging as it is, remains more suggestive than systematic. This prompts a question about whether such systematicity - so central to contemporary "analytical" political philosophy, and thus to the mainstream debates over global justice - is itself something compatible with or antithetical to the realist sensibility.

\section{Realism and Global Justice}

Bernard Williams wrote short essays on humanitarian intervention and human rights (2005: 6275, 145-54), but they add little to the existing literature and neither discuss how the central concept of his realism - the Basic Legitimation Demand (BLD) - might be utilised in assessing the legitimacy of international institutions or practices. Geuss's provocative writings on realism include brief asides about the depredations of global capitalism and the evils of the Iraq war (e.g. 2008: 31, 33, 98), but no sustained account of either, or of how a radical realist should theorise the current international order. Even in his instructive E. H. Carr lecture, dedicated to one of the most important realist IR thinkers, Geuss focuses more on philosophical questions about relativism and the meaning of utopia than on the kind of political issues that preoccupied Carr. Both liberal and radical realists face a major challenge in developing theories that can encompass international relations. A few scholars have already begun to explore the terrain.

Matt Sleat (2016) has started to build a Williams-inspired realist account, though he is hesitant about its viability: "it really is far from clear whether realist theory can be applied to the international sphere at all” (2016b: 170). This worry stems from his definition of politics. He

5 One important point to mention here is that many of the key mid-century realists, including Morgenthau and Herz, were émigrés: the story of realism in the US is in part the story of the importation of German traditions of political thinking into an American academic context. The literature on Morgenthau is large and continues to grow. For recent significant accounts, see (among others): Jütersonke 2010; Rösch 2015; Scheuerman (2009); Schuett (2010); Tjalve (2008); Williams (2007). For the émigré context in which Morgenthau needs to be located, see Rösch (2014); on institutional-disciplinary contexts, see Guilhot (2011); Vitalis (2015). For a discussion of disciplinary history in IR, see Bell (2009).

${ }^{6}$ For contrasting revisionist accounts, in which the reimagining of realism plays a central role, see Schmidt (1997, 2012); Guilhot (2008, 2011a,b). 
starts from the position that politics is the "attempt made by human beings to live together collectively under a common authority that has the right to make commonly binding decisions and to employ (legitimate) coercive power to enforce obedience with those decisions, if required" (2016: 69). While this does not conflate politics with the sovereign state, it draws a very close connection between them. From this perspective, war, genocide, ethnic cleansing, and imperial domination, all mark the failure or absence of politics not a perverse instantiation of it. The scope of international political theory is thus limited. Indeed Sleat argues that the aim of a realist theorisation of international order would be to explore the potential legitimation of existing (or future?) international institutions, rather than (say) the development of egalitarian accounts of distributive justice (2016b: 181). ${ }^{7}$ Realism, on such an account, is not equivalent to existing theories of global justice, but is better seen as "challenging a particular way of thinking about the problem in the first place" (2016b: 170). It stands as a critique of global justice, rather than a variant of it.

It does not follow, however, that realists must remain silent about international affairs. For example, in a recent article Sleat aims to recast the Responsibility to Protect (R2P), which is typically characterised in thoroughly moralistic terms. He starts by offering an account of the wrongs R2P addresses that does not depend on extra-political claims about individual autonomy, human rights or dignity. The "first question of politics," as Bernard Williams put it, concerns the provision of security, stability and order. These are the necessary foundations for the pursuit of politics as a means of reaching binding (legitimate) decisions in contexts of severe disagreement. R2P thus applies when that first question remains unanswered - when states are either unwilling or unable to secure the conditions necessary for the pursuit of politics. The second strand of his argument explains why states might have a duty to intervene. Because political relationships are relationships of legitimate rule between the governed and the governors, they do not occur between political communities, which thus exist in a kind of political vacuum. Insofar as states or individuals have responsibilities to those beyond their borders, then, it is necessary to call upon non-political moral values. Such values will need to be seen as legitimate by both the population engaged in the intervention and those subjected to it - without this dual legitimation, the intervention will be an act of domination or war. Given the fact of global cultural and political diversity, this means that arguments based on universal claims about the superiority of liberal democratic principles are bound to fail. Instead Sleat invokes the "liberalism of fear," as elaborated by Shklar and endorsed by Bernard Williams (2005: 52-62). R2P responds to acts that it is reasonable to assume all persons fear - acts of indiscriminate violence and cruelty: "the universality of these evils might offer a slender but potentially sufficient way of making sense of interventions as legitimate to and for both parties" (Sleat 2016: 76). He concludes by (re)defining the R2P:

The RtoP is therefore an attempt to maintain ... or create ... relationships of political rule in those places where they are at risk or have already deteriorated, as evidenced by acts of genocide, war crimes, ethnic cleansing and crimes against humanity, which we can make sense of as legitimate in virtue of its responding to the internal demands of politics of

\footnotetext{
${ }^{7}$ Sleat argues that "statist" positions in the global justice debates - e.g those generated by Thomas Nagel, Andrea Sangiovanni, and Michael Blake - are instances of moralism not realism (2016b: 173-6).
} 
creating order and stability in such a way that protects individuals from fear of those common human evils (2016: 77).

Sleat's argument depends on a restrictive and debatable definition of politics. Nevertheless it provides a liberal realist response to some of the core ethico-political questions in international relations. Intriguingly, it also opens the door to an account of distributive justice, in a way that realists have so far done very little to explore. Arguments invoking the "first political question" can be applied to abject poverty and deprivation; without securing a decent standard of living it is impossible for politics (as Sleat understands it) to get off the ground. Likewise, the "liberalism of fear" could be adapted to such situations in order to justify external redress. While such an argumentative strategy would not generate a fully-fledged cosmopolitan theory of distributive justice, it might nevertheless provide grounds for a significant redistribution of resources, and as such go some way to fleshing out what a liberal realist account of global justice might encompass.

Terry Nardin has carved out a different realist path (2017a; 2017b; 2013; 2011). His is not a theory composed of (or issuing in) a bundle of moral prescriptions to guide action, but rather an "explanatory" theory tasked with providing an internally coherent account of global justice that gives due attention to the complex interconnections between morality, interests and institutions in a system of states. Such a theory

...recognizes that where the actions of public authorities are concerned, moral considerations are mediated by law. What is right and wrong in governing is determined not by unmediated moral principles (though moral concerns can never be ignored), nor by consequrentialist reasoning (even though assessing costs and benefits is important), but primarily by reasons arising from the existence of public authority (2013: 61).

The theory - "justice as justifiable coercion" - is grounded in an account of the justifiability of public authority. Such authority is characterised in part by its coercive character; to be legitimate such coercion must be justifiable. It must sustain freedom as independence (or nondomination). Nardin contends that his theory can both explain the potential legitimacy of states while addressing central issues in international political theory, including the justifiability of military force and questions of global poverty. Consequently, it avoids the scope problem that Sleat acknowledges in his own account. For Nardin - and here the argument overlaps with much classical just war thinking - states have a right of sovereign independence analogous to natural persons, thus generating a qualified right to non-intervention (and self-defence). But when a state turns on its people, or when one state aggressively attacks another, their right of noninterference is curtailed, thus allowing for the possibility of a legitimate military intervention to restore the status quo ante. Again, this position differs from Sleat's defence of R2P, insofar as it doesn't invoke pre-political moral values, however thin. Nardin further argues that severe poverty can be incorporated within his theory. The problem with such poverty - from the perspective of a theory of justice - is "not that people are suffering or that there are economic inequalities" but rather that "the poor are dependent on the decisions of others" (2013: 54). They are subject to a system of domination, and therefore economic redistribution can be justified through reference to "freedom rather than interest" (2013: 54). Nardin acknowledges that his account is only a sketch, but at present it is the most ambitious realist theorisation of global justice. It is ironic, then, that his theory is heavily (and explicitly) indebted to Kant, who is 
so often read as the antithesis of realism (Nardin 2017a, b; see Tuck 1999: 197-226 for another realist interpretation). ${ }^{8}$

Radical realist theories of global politics look very different, though they too come in various forms. ${ }^{9}$ Given his interest in unmasking the dynamics of dominance, and the hypocrisy of actually existing liberal foreign policy, Noam Chomsky's work can be read as a contribution to the realist project of critique (Osborn 2009). Chantal Mouffe (2005; 2013), meanwhile, has outlined a left-Schmittian international theory. Without mentioning IR realism, she ends up defending a vision of world politics that is remarkably similar to its most hard-edged versions. This is perhaps unsurprising, given that some of the most influential classical realists, notably Morgenthau, honed their thinking in critical dialogue with Schmitt (Scheuerman 2007, 2009; Koskenniemi 2001). For Mouffe, cosmopolitanism is a dangerous "post-political" fantasy of world order - it seeks to efface the inherent plurality, and the clash of interests and identities, that constitute a healthy agonistic politics. Foreclosing the "possibility of legitimate dissent," it is an unjust and counterproductive exercise in hegemonic imposition. Indeed she suggests that attempts to promote a universal political-economic model - liberal democratic capitalism spawn violent resistance, thus destabilising the fragile international order. This creates the "terrain for the emergence of violent forms of antagonisms" (2009: 552). The aim, then, is to forge a world in which "antagonism" (potentially violent contestation between enemies) is replaced by vigorous "agonism" (non-violent contestation between adversaries). To foster this global agonistic space, she argues for a "multipolar" world order based around "a plurality of centres of decision-making and some sort of equilibrium - even if it is only a relative one among various powers" (2005: 116). This points towards a "pluralisation of hegemonies" - the coexistence of regional powers balancing one another - though Mouffe has not yet fleshed out the details of this picture. ${ }^{10}$

Geuss argues that one of the main tasks of realism is to engage in Ideologiekritik, the project of unmaking the norms and beliefs that legitimate and reproduce the status quo (Geuss 2016; Prinz 2016; Finlayson 2016). Although he doesn't develop the argument, this ambition underpins his scepticism about human rights, which he describes as "inherently vacuous" and "a kind of puffery or white magic" (Geuss 2001: 164). The magical properties of human rights serve a malign political purpose: "what actually happens in the international regime of human rights even as it is defined by the United Nations is that the powerful countries use claims about rights to further their interests. They act to enforce rights when that is in their interests, and they try to prevent action when it is not in their interests" (2013: 140). From this perspective, much of the liberal global justice discourse serves (unintentionally) to reinforce the existing order rather than transforming it, chiefly through distracting attention away from the pivotal role of liberalism in perpetuating injustice. This line fits neatly into the radical tradition - one of the main aims of Carr's work, for example, was to expose the self-serving hypocrisy of much Western discourse of international relations, and in particular about the purported universal benefits of free market capitalism (Carr 1939).

\footnotetext{
${ }^{8}$ Michael Oakeshott is another influence on Nardin's work (see also Nardin 1983). For other Oakeshottian accounts of international order, see Jackson (2003); Rengger (2013).

${ }^{9}$ See, for example, the special edition of the Journal of International Political Theory (2016, OnLine First), dedicated to exploring connections between critical theory and classical realism.

${ }^{10}$ Other left-Schmittian accounts of international politics include Zolo (1997); Odysseos \& Pettito (2007). For an argument that realists should reject the Schmittian influence, see Scheuerman (2017).
} 
Realists insist that viable political theories should incorporate or address the norms, institutions and practices of politics. Yet there are some vitally important areas that realists have yet to explore. While radical realists stress the depredations of capitalism, and the way in which it structures geopolitical ordering, they (like liberal realists) have not interrogated other forms of global structural domination, notably those of gender and race. ${ }^{11}$ They are not alone. Such concerns (and especially the latter) have so far received little attention in the global justice literature (Mills 2015; Bell 2017b). ${ }^{12}$ Yet if realism is to be realistic about the world it purports to comprehend it must grapple directly with the legacies of gender oppression, projects of racial supremacy, and imperialism.

\section{Conclusion}

Realism is a thriving research agenda in both IR and political theory. Scholars working in this vein have much to contribute to normative debates about international politics. But it is important to recognise the significant differences among realists. They offer conflicting answers to many methodological, political and ethical questions. While neo-positivist realism might help political theorists think about questions of feasibility and the problems (and opportunities) of enacting reform in the international system, other realists reject their methodological framework. An alternative strand of realist international political theorising, meanwhile, has both shed light on important themes in the history of twentieth century political thought and generated a richly suggestive body of arguments about the role of power, interests and identity in the international system. More recently, political philosophers have begun to flesh out realist insights, either to enrich the liberal tradition or to reject it. They are beginning to develop realist positions in the debates over global justice.

The renaissance of realist political thinking is a welcome development. However, it will remain hamstrung unless we see greater cross-fertilisation between political theorists and IR scholars. Political theories cannot be seen as realistic unless they can encompass international institutions, practices and norms. Although there are encouraging signs that signs that this problem is being addressed, both liberal and radical realists have much work to do.

\section{Bibliography}

Beitz, Charles (1979/1999) Political Theory and International Relations, rev. ed. Princeton: Princeton University Press.

Bell, Duncan (ed.) (2008a) Political Thought and International Relations: Variations on a Realist Theme. Oxford: Oxford University Press.

- (2008b) "Under an Empty Sky - Realism as Political Theory" in Bell (ed.), Political Thought and International Relations

- (2009) "Writing the World: Disciplinary History and Beyond," International Affairs, 85/1, $3-22$

\footnotetext{
${ }^{11}$ For an early feminist critique of realism, see (Elshtain 1985); for a compelling argument that feminism is compatible with some forms of realism, see Frazer (2017), although she doesn't discuss international relations.

${ }^{12}$ James Tully's work has been described as realist (Honig and Stears 2011). However, the label is an awkward fit. Tully offers one of the most penetrating accounts of the ways in which the history of western imperialism has shaped (and continues to shape) the international system, and in that sense he can be read as a radical realist. But his prescriptions for addressing this situation are, I would argue, far more optimistic than a realist would typically countenance (Bell 2014b).
} 
- (2014a) "What is Liberalism?" Political Theory, 42/6: 682-715

- (2014b) "To Act Otherwise: Agonistic Republicanism and Global Justice" in David Owen (ed.), On Global Citizenship: James Tully in Dialogue. London: Bloomsburg.

- (2017a) "Security and Poverty: On Realism and Global Justice" in Sleat (ed.) Realist Political Thought

- (2017b) "Realist Challenges" in Chris Brown and Robyn Eckerseley (eds.), The Oxford Handbook of International Political Theory. Oxford: Oxford University Press.

- (2017c) (ed.), Empire, Race and Global Justice

Craig, Campbell (2003) Glimmer of a New Leviathan: Total War in the Realism of Niebubr, Morgenthan and Waltr. New York: Columbia University Press.

Carr, E. H. (1956/1939) The Twenty Years' Crisis, 1919-1939: An Introduction to Study International Relations. London: Macmillan.

Coady, C. A. J. (2008) Messy Morality: The Challenge of Politics. Oxford: Oxford University Press.

Cozette, Muriel (2008) "Reclaiming the Critical Dimension of Realism: Hans J. Morgenthau and the Ethics of Scholarship," Review of International Studies, 34(1), 5-27.

Deudney, Daniel H. (2007) Bounding Power: Republican Security Theory From the Polis to the Global Village. Princeton: Princeton University Press.

Donnelly, Jack (2008) “The Ethics of Realism” in Christian Reus-Smit and Duncan Snidal (eds.), The Oxford Handbook of International Relations. Oxford: Oxford University Press.

- (2000) Realism in International Relations. Cambridge: Cambridge University Press.

Elshtain J. B. (1985) "Reflections on War and Political Discourse: Realism, Just War, and Feminism in a Nuclear Age," Political Theory, 13/1: 39-57

Finlayson, Lorna (2016) The Political is Political: Conformity and the Illusion of Dissent in Contemporary Political Philosophy. Rowman \& Littlefield.

- (2015) "With Radicals Like These, Who Needs Conservatives? Doom, Gloom and Realism in Political Theory," European Journal of Political Theory [Online First]

Fiott, Daniel (2013) "Realist Thought and Humanitarian Intervention," International History Review, 35/4: 766-82.

Frazer, Elizabeth (2017) "Feminism and Realism" in Sleat (ed.), Realist Political Thought

Galston, William (2010) "Realism in Political Theory," European Journal of Political Theory, 9/4: 385-411

Lawford-Smith, Holly (2013) "Understanding Political Feasibility," Journal of Political Philosophy, 21/3: 243-59

Geuss, Raymond (2001) History and Illusion in Politics. Cambridge: Cambridge University Press.

- (2005) Outside Ethics. Princeton: Princeton University Press.

- (2008) Philosophy and Real Politics. Princeton: Princeton University Press.

- (2013) "Human Rights: A Very Bad Idea," interview with Lawrence Hamilton, Theoria, 63/2: 83-103 
- (2015) "Realism and the Relativity of Judgement," International Relations, 29/1 (2015), 3-22

- (2016) Reality and its Dreams. Cambridge, M.A.: Harvard University Press.

Guilhot, Nicolas (2008) "The Realist Gambit: Postwar American Political Science and the Birth of IR Theory," International Political Sociology, 2/4: 281-304.

- (ed.) (2011) The Invention of International Relations Theory: Realism, the Rockefeller Foundation, and the 1954 Conference on Theory. New York: Columbia University Press.

Guzzini, Stefano (1998) Realism in International Relations and International Political Economy: The Continuing Story of a Death Foretold, London: Routledge.

Habermas, Jürgen (2006) The Divided West, trans. Ciaran Cronin. Cambridge: Polity.

Hacke, Christian and Jana Puglierin (2007), "John H. Herz: Balancing Utopia and Reality', International Relations, $21 / 3$

Haslam, Jonathan (2004) No Virtue Like Necessity: Realist Thought in International Relations Since Machiavelli. London: Yale University Press.

Herz, John (1981), "Political Realism Revisited: Response," International Studies Quarterly, 25/2: 201-203

- (1951) Political Realism and Political Idealism. A Study in Theories and Realities. Chicago: Chicago University Press.

Hoffman, Stanley (1977) “An American Social Science: International Relations,” Deadalus, 106:3, 41-59

- (1981) Duties Beyond Borders: On the Limits and Possibilities of Ethical International Politics, Syracuse: Syracuse University Press.

- (1995a) "The Politics and Ethics of Military Intervention," Survival, 37/4: 29-51

- (1995b) “The Crisis of Liberal Internationalism," Foreign Affairs, 98: 155-77

- (1998a) "Editor's Preface" in Judith Shklar, Political Thought and Political Thinkers, ed.

Hoffmann. Chicago: University of Chicago Press.

- (1998b) World Disorders: Troubled Peace in the Post-Cold War Era.

Honig, Bonnie and Stears, Marc (2011) "The New Realism: From Modus Vivendi to Justice" in Jonathan Floyd and Marc Stears (eds.), Political Philosophy versus History? Contextualism and Real Politics in Contemporary Political Thought. Cambridge: Cambridge University Press.

Jackson, Robert (2003) The Global Covenant: Human Conduct in a World of States. Oxford: Oxford University Press.

Jackson, Patrick Thaddeus (2010) The Conduct of Inquiry in International Relations: Philosophy of Science and its Implications for the Study of World Politics. London: Routledge.

Jütersonke, Oliver (2010) Morgenthau, Law and Realism. Cambridge: Cambridge University Press.

Koskenniemi, Marttii (2000) "Carl Schmitt, Hans Morgenthau, and the Image of Law in International Relations" in Michael Byers (ed.), The Role of Law in International Politics: Essays in. International Relations and International Law. Oxford: Oxford University Press 
Kostagiannis, Konstantinos (2014) "Hans Morgenthau and the Tragedy of the Nation-State," International History Review, 36/3: 513-29

Lebow, Richard Ned (2003) The Tragic Vision of Politics: Ethics, Interests, and Orders. Cambridge: Cambridge University Press.

McQueen, Alison (2017a) “The Case for Kinship: Classical Realism and Political Relaism" in Sleat (ed.), Realist Political Thought

Political Realism in Apocalyptic Times. Cambridge: Cambridge University Press.

- (2017c) "Political Realism and Moral Corruption," European Journal of Political Theory (forth.)

- (2017d) "Political Realism and the Realist Tradition," Critical Review of Social and Political Philosophy (forth.)

Mearsheimer, John (2001) The Tragedy of Great Power Politics. New York: W. W. Norton.

Mills, Charles (2015) "Race and Global Justice" in Barbara Buckinx, Jonathan Trejo-Mathys, and Timothy Waligore (eds.), Domination and Global Political Justice: Conceptual, Historical and Institutional Perspectives. Abingdon: Routledge

Mollov, M. Benjamin (2002) Power and Transcendence: Hans J. Morgenthan and the Jewish Experience.

Boulder: Lexington Books.

Molloy, Seán (2006) The Hidden History of Realism. A Genealogy of Power Politics, Houndmills: Palgrave Macmillan.

Morgenthau, Hans J. (1967) Politics among Nations: The Struggle for Power and Peace, $4^{\text {th }}$ ed. New York: Alfred A. Knopf.

- (1962) "International Relations," Encyclopaedia Britannica (1961), repr. in Morgenthau, The Restoration of American Politics: Politics in the Twentieth Century, Vol. 3. Chicago: University of Chicago Press, 167-75

Mouffe, Chantal (2009) "Democracy in a Multipolar World," Millennium: Journal of International Studies, 37: 549-63

- (2005) On the Political. London: Routledge

Munster, Rens van \& Casper Sylvest (2017) "Re-Imagining Reality: Realism under a Dark Sun" in Sleat (ed.), Realist Political Thought

- (2016) Nuclear Realism: Global Political Thought during the Thermonuclear Revolution. London: Routledge

- (2014) "Reclaiming Nuclear Politics? Nuclear Realism, the H-bomb and Globality," Security Dialogue, 45/6, 530-47

Nardin, Terry (2017a) "Kant's Republican Theory of Justice and International Relations," International Relations (forth.)

- (2017b) "The New Realism and the Old," Critical Review of International Social and Political Philosophy (forth.)

- (2013) 'Realism and Right: Sketch for a Theory of Global Justice' in Cornelia Navari (ed.), Ethical Reasoning in International Affairs: Arguments for the Middle Ground. Palgrave Macmillan, 43-63. 
- (2011) "Justice and Authority in the Global Order," Review of International Studies 37, 2059-72

Nili, Shmuel (2016) "Liberal Global Justice and Social Science," Review of International Studies, 42, 136-55

Odysseos, Louisa \& Pettito, Fabio (eds.), The International Political Thought of Carl Schmitt: Terror, Liberal War and the Crisis of Global Order. Abingdon: Routledge.

Osborn, Ronald (2009) "Noam Chomsky and the Realist Tradition," Review of International Studies, 35: $351-70$

Prinz, Janosch (2016) "Raymond Geuss' Radicalization of Realism in Political Theory," Philosophy \& Social Criticism, 42:8, 777-96

Rengger, N. (2013) Just War and International Order: The Uncivil Condition in World Politics. Cambridge: Cambridge University Press.

Rösch, F. (2015) Power, Knowledge, and Dissent in Morgenthau's Worldview. Basingstoke: Palgrave Macmillan

- (2014) Emigré Scholars and the Genesis of International Relations: A European Discipline in America? Basingstoke: Palgrave Macmillan.

Rosenthal, Joel H. (1991) Righteous Realists: Political Realism, Responsible Power, and American Culture in the Nuclear Age. Baton Rouge: Louisiana State University Press.

Rossi, Enzo \& Matt Sleat (2014) "Realism in Normative Political Theory," Philosophy Compass, 9/10: 689-701

Runciman, David (2016) "Political Theory and Real Politics in the Age of the Internet," Journal of Political Philosophy [early view]

- (2006) The Politics of Good Intentions: History, Fear and Hypocrisy in the New World Order. Princeton: Princeton University Press.

Russell, Greg (1990) Hans J. Morgenthan and the Ethics of American Statecraft. Baton Rouge: Louisiana State University Press.

Scheuerman, William (2017) "Getting Past Schmitt? Realism and the Autonomy of Politics" in Sleat (ed.), Realist Political Thought

- (2014) "Cosmopolitanism and the World State," Review of International Studies, Vol. 40, No. 3.

- (2013) "The Realist Revival in Political Philosophy, Or: Why New is Not Always Improved," International Politics, 50/6: 798-814

- (2010) "The (Classical) Realist Vision of Global Reform," International Theory, Vol. 2, No. 2

- (2011) The Realist Case for Global Reform. Cambridge: Polity.

- (2009) Hans J. Morgenthau: Realism and Beyond. Cambridge: Polity.

- (2007) "Carl Schmitt and Hans Morgenthau: Realism and Beyond" in Williams (ed.), Realism Reconsidered

Schmidt, Brian, (ed.) (2012) International Relations and the First Great Debate. London: Routledge (1997) The Political Discourse of Anarchy: A Disciplinary History of International Relations. Albany: SUNY Press. 
Schuett, Robert (2010) Political Realism, Freud, and Human Nature in International Relations. New York: Palgrave.

Schweller, Randall (2006), Unanswered Threats: Political Constraints on the Balance of Power. Princeton: Princeton University Press.

Shklar, Judith (1989) "The Liberalism of Fear" in Nancy Rosenblum (ed.), Liberalism and the Moral Life. Cambridge, Mass.: Harvard University Press

Sleat, Matthew (2013) Liberal Realism: A Realist Theory of Liberal Politics. Manchester: Manchester University Press.

- (ed.) (2017) Realist Politics Thought: Confronting Conflict, Motivation, and Morals in Institutions and Practices. New York: Columbia University Press.

- (2016a) 'The Politics and Morality of the Responsibility to Protect: Beyond the Realist/Liberal Impasse,' International Politics, 53/1, 67-82

- (2016b) "The Value of Global Justice: Realism and Moralism," Journal of International Political Theory, 12/2, 169-84

Smith, Michael Joseph (1986) Realist Thought from Weber to Kissinger. Baton Rouge: Louisiana State University Press.

Stirk, Peter (2005) "John H. Herz: Realism and the Fragility of the International Order," Review of International Studies, 31:. 285-306

Sylvest, Casper (2014) "Russell's Realist Radicalism," International History Review, 36, 1-18

- (2007), "John H. Herz and the Resurrection of Classical Realism," International Relations, 22/4: 441-55.

Tjalve, Vibeke S (2008) Realist Strategies of Republican Peace: Niebubr, Morgenthau, and the Politics of Patriotic Dissent. New York: Palgrave.

Tuck, Richard (1999) The Rights of War and Peace: Political Thought and the International Order from Grotius to Kant. Oxford: Oxford University Press.

Vitalis, Robert (2016) White World Order, Black Power Politics: The Birth of American International Relations. New York: Columbia University Press.

Waltz, Kenneth (1979) Theory of International Politics. Reading, MA.: Addison-Wesley.

Williams, Bernard (2005a) In the Beginning was the Deed: Realism and Moralism in Political Argument, ed. Geoffrey Hawthorn. Princeton: Princeton University Press,

Williams, Michael C. (2001) "Securitization and the Liberalism of Fear," Security Dialogue, 42: 4-5, 453-63

(2005) The Realist Tradition and the Limits of International Relations. Cambridge: Cambridge University Press.

- (2007) (ed.), Realism Reconsidered: The Legacy of Hans Morgenthan in International Relations, Oxford: Oxford University Press.

- (2011) "Securitization and the Liberalism of Fear," Security Dialogue, 42/4-5: 453-63 
Wohlforth, William (2008) "Realism" in Christian Reus-Smit and Duncan Snial (eds.) The Oxford Handbook of International Relations.

Zimmer, Louis B. (2011) The Vietnam War Debate: Hans J. Morgenthau and the Attempt to Halt the Drift into Disaster. Boulder: Lexington.

Zolo, Danilo (2007) Cosmopolis: Prsopects for World Government. Cambridge: Polity. 